\title{
Characterization and Cell Viability of Probiotic/Prebiotics Film Based on Duck Feet Gelatin: A Novel Poultry Gelatin as a Suitable Matrix for Probiotics
}

\author{
Ahmadreza Abedinia ${ }^{1}$ (D), Faezeh Alimohammadi ${ }^{2}$, Farangis Teymori ${ }^{1}$, Najibeh Razgardani ${ }^{3}$, \\ Mohammad Reza Saeidi Asl ${ }^{4}$, Fazilah Ariffin ${ }^{5, *}$, Abdorreza Mohammadi Nafchi 1,5,*D, Nurul Huda 6,7,*(D) \\ and Jumardi Roslan 6
}

check for updates

Citation: Abedinia, A.;

Alimohammadi, F.; Teymori, F.; Razgardani, N.; Saeidi Asl, M.R.; Ariffin, F.; Mohammadi Nafchi, A.; Huda, N.; Roslan, J. Characterization and Cell Viability of Probiotic/ Prebiotics Film Based on Duck Feet Gelatin: A Novel Poultry Gelatin as a Suitable Matrix for Probiotics. Foods 2021, 10, 1761. https://doi.org/ 10.3390 /foods 10081761

Academic Editors: Maria Grazia Volpe and Monique Lacroix

Received: 20 April 2021

Accepted: 23 June 2021

Published: 30 July 2021

Publisher's Note: MDPI stays neutral with regard to jurisdictional claims in published maps and institutional affiliations.

Copyright: (c) 2021 by the authors Licensee MDPI, Basel, Switzerland. This article is an open access article distributed under the terms and conditions of the Creative Commons Attribution (CC BY) license (https:// creativecommons.org/licenses/by/ $4.0 /)$.
1 Food Biopolymer Research Group, Food Science and Technology Department, Damghan Branch, Islamic Azad University, Damghan 36711, Iran; raabediniar@gmail.com (A.A.); farangisteymoori66@gmail.com (F.T.)

2 Young Researchers and Elite Club, Shahr-e-Qods Branch, Islamic Azad University, Tehran 37541, Iran; alimohammadi.faezeh@yahoo.com

3 Department of Food Science and Technology, Garmsar Branch, Islamic Azad University, Garmsar 35811, Iran; najibehrazgordani@gmail.com

4 Department of Food Science and Technology, Sabzevar Branch, Islamic Azad University, Sabzevar 96131, Iran; dr.saeidi@iaus.ac.ir

5 Food Biopolymer Research Group, Food Technology Division, School of Industrial Technology, Universiti Sains Malaysia, Minden 11800, Penang, Malaysia

6 Faculty of Food Science and Nutrition, Universiti Malaysia Sabah, Kota Kinabalu 88400, Sabah, Malaysia; jumardi@ums.edu.my

7 Department of Food Science and Technology, Faculty of Agriculture, Universitas Sebelas Maret, Surakarta 57126, Central Java, Indonesia

* Correspondence: fazilah@usm.my (F.A.); amohammadi@usm.my (A.M.N.); drnurulhuda@ums.edu.my (N.H.)

Abstract: The probiotic viability, physicochemical, mechanical, barrier, and microstructure properties of synbiotic edible films (SEFs) based on duck feet gelatin (DFG) were evaluated. Four synbiotic systems were obtained by mixing four types of prebiotics, namely, dextrin, polydextrose, gum Arabic, and sago starch, with DFG to immobilize of probiotic (Lactobacillus casei ATCC). The ability of DFG to create a suitable matrix to increase probiotic viability was compared with those of other commercial gelatins in a preliminary evaluation. The DFG showed proper probiotic viability compared with other gelatins. The addition of prebiotics reduced the transparency of SEFs and increased color differentiation, uniformity, and complete coverage of probiotic cells. The estimated shelf-life of surviving bacteria in the SEFs stored at 4 and $25^{\circ} \mathrm{C}$ showed that gum arabic showed the best performance and enhanced the viability of $L$. casei by $42 \%$ and $45 \%$, respectively. Dextrin, polydextrose, and sago starch enhanced the viability of $L$. casei at 4 and $25{ }^{\circ} \mathrm{C}$ by $26 \%$ and $35 \%, 26 \%$ and $5 \%$, and $20 \%$ and $5 \%$, respectively. The prebiotics improved the physicochemical, mechanical, and barrier properties of all SEFs, except polydextrose film. The viability of L. casei can be increased with the proper selection of gelatin and prebiotics.

Keywords: duck feet gelatin; synbiotic edible film; probiotic viability

\section{Introduction}

The probiotics global market in 2014 was valued at 62.6 billion dollars; in 2020, it was valued at 96.0 billion dollars [1]. Probiotics are live microorganisms that confer health benefits on the host through the maintenance of normal intestinal microflora; suitable probiotic organisms are administered at a sufficient number, i.e., $>6-7 \log$ colony-forming unit (CFU)/g. However, some studies have reported limitations in terms of the probiotics dose. The appropriate dose for the effective use of probiotics is less than $\left(10^{9} \mathrm{CFU} /\right.$ day $)$. 
Therefore, the validity of studies that do not consider the minimum consensus of appropriate probiotic dosages in their results is questioned [2]. Some of the probiotic benefits include the following: enhancement of the immune system, which in turn affects the severity and prevention of and susceptibility to COVID-19 [3]; protection against gastrointestinal pathogens [4]; reduction of serum cholesterol level and blood pressure [5]; anti-carcinogenic activity [6]; and the improvement of absorption and utilization of nutrients from food [7,8]. Probiotics have many therapeutic applications, as reported by Dhillon and Singh [9]. Generally, Lactobacilli, Bifidobacteria, and Saccharomyces are generally recognized as safe (GRAS) by the WHO [10].

One of the biggest problems that leads to failure is the viability of the required number of probiotic bacteria in the path of production and in the digestive tract pathway [11]. The content of probiotic bacteria in food right before ingestion is suggested to be in the range of $10^{8}-10^{9} \mathrm{CFU} / \mathrm{g}$ to ensure the adequate therapeutic minimum of $10^{6}-10^{7} \mathrm{CFU} / \mathrm{g}$ colon in the final product [12].

Various methods have been developed to increase the survival of probiotics, among which microencapsulation is the most useful. The combination of microencapsulation with active edible packaging represents a promising strategy for the adequate protection and delivery of probiotic species $[1,13]$. The production of edible films and coatings as stabilizing matrices of probiotics allows them to reach the intestines in sufficient quantities [14].

Various biopolymers have been used as carrier matrices of probiotics, such as the following: kefiran [15], low esterified amidated pectin, kappa-carrageenan/locust bean gum and gelatin [16], carboxymethyl cellulose (CMC) [17], poly(vinyl alcohol), hydroxypropyl methylcellulose and corn starch [18], CMC and hydroxyethyl cellulose [19,20], gum Arabic (GA), maltodextrin and whey protein concentrate (WPC) [21], cassava starch (CS)/CMC [22,23], CMC nanofibers [24], chitosan-coated agar-gelatin gel particles [25], and Konjac glucomannan [26].

Gelatin is a very suitable vehicle for encapsulating bioactive compounds, such as probiotics living cells [27] and microencapsulating agents [28]. Poultry gelatins, such as duck feet gelatin (DFG) and chicken skin gelatin (CSG), have excellent film-forming properties [29,30]. One of the primary functions of food packaging is to reduce moisture transition between products and the surrounding atmosphere. Low water-vapor permeability (WVP) widens the composite packaging film utilization, especially in a high-moisture environment [31]. The WVP value of CSG film was low at $1.36 \times 10^{-4} \mathrm{~g} \mathrm{~m}^{-1} \mathrm{~s}^{-1} \mathrm{~Pa}^{-1}$. That of DFG was $5 \times 10^{-11} \mathrm{~g} \mathrm{~m}^{-1} \mathrm{~s}^{-1} \mathrm{~Pa}^{-1}$ [32], whereas that of bovine gelatin (BG) film was $2.5 \times 10^{-10} \mathrm{~g} \mathrm{~m}^{-1} \mathrm{~s}^{-1} \mathrm{~Pa}^{-1}$ [33]. Poultry gelatin, when extracted optimally, contains more than twice as much collagen as commercial gelatin, which makes poultry gelatin more economically and nutritionally cost effective [34].

Prebiotic is a nondigestible ingredient that beneficially affects the host by selectively stimulating the growth and/or activity of one or a limited number of bacteria in the colon without improving the well-being and health of unwanted bacteria. Some biopolymers, including gum arabic (GA), polydextrose (Poly), dextrin (Dex), and starch, have a prebiotic effect on food systems. The synergistic combinations of probiotics and prebiotics are called synbiotics [26].

This study aimed to develop and characterize DFG-based bioactive films containing $L$. casei ATCC 393 cells incorporated with four prebiotics, namely, sago starch (SS), GA, Poly, and Dex for the first time. This bioactive film can be used as an edible coating or film of ready-to-eat meat products, processed cheeses, and dried fruits.

\section{Materials and Methods}

\subsection{Materials, Bacterial Strains, and Culture Conditions}

BG (G9382; 225 g Bloom) and prebiotic fibers, such as dextrin from maize starch (CAS No. 9050-36-6) and polydextrose (Promitor), were purchased from Sigma-Aldrich and Tate and Lyle GmbH, (Darmstadt, Germany), respectively. The DFG was extracted by acetic acid according to the method described by Abedinia, Ariffin, Huda, and Nafchi [29] 
at the School of Industrial Technology, Universiti Sains Malaysia. Fish gelatin (FG) was extracted from tilapia skin gelatin according to the method of Tan et al. [35]. Gum arabic (molecular weight: 250,000) and sago starch $(10 \%$ moisture; a mean diameter of $37.59 \mu \mathrm{m}$ of granules) were purchased from SIM Supplies Company (Penang, Malaysia).

Lyophilized commercial cultures of L. casei ATCC 393 used for immobilization were obtained from DSMZ, Germany. Preparation of stock culture was performed as described by Sidira et al. [36] The probiotic was grown on MRS broth (Merck, Darmstadt, Germany) at $37^{\circ} \mathrm{C}$ for $72 \mathrm{~h}$. The cell culture broth in the stationary bacterial growth stage was aseptically transferred to sterile $50 \mathrm{~mL}$ plastic centrifuge tubes (Sarstedt Ltd., Leicester, UK) and centrifuged at $3000 \times g$ for $5 \mathrm{~min}$. The supernatant liquid was discarded, and the harvested bacterial cells were washed twice with phosphate-buffered saline (PBS) (Dulbecco A, Oxoid Ltd., Basingstoke, UK).

\subsection{Preparation of the Probiotic and Synbiotic Films}

The probiotic gelatin films (Pro-DFG, Pro-BG, and Pro-FG) were prepared. The ability of DFG to create a suitable and protective matrix to increase probiotic viability was compared with that of other commercial gelatins. Gelatins (DFG, BG, and FG) at $4 \mathrm{~g}$ each were weighted in a $200 \mathrm{~mL}$ Duran Schott bottle, and $1 \mathrm{~g}$ glycerol (equivalent of $25 \%$ of biopolymer; $\geq 99 \%$, Fischer Scientific, Loughborough, UK) was weighed in a beaker. Glycerol was dissolved in $50 \mathrm{~mL}$ of distilled water then mixed with the gelatins. The mixture was heated for $30 \mathrm{~min}$ at $50^{\circ} \mathrm{C}$ for hydration, and film-forming solutions (FFSs) were obtained.

To develop a DFG bioactive film, the synbiotic edible films (SEFs) (Syn-DFG/Dex, Syn-DFG/Poly, Syn-DFG/GA, and Syn-DFG/SS) were prepared. The prebiotics were added to $50 \mathrm{~mL}$ of distilled water at $50{ }^{\circ} \mathrm{C}$ at $2 \mathrm{~g}$. In a separate beaker, $4 \mathrm{~g}$ of DFG was added to create five individual biopolymer solutions. Glycerol as a plasticizer was added to all solutions at $25 \%$ of biopolymer total solid material. DFG solution was heated for $30 \mathrm{~min}$ at $50{ }^{\circ} \mathrm{C}$ for hydration and mixed at 1:1 with the prebiotic solutions to make FFSs.

The FFSs were neutralized by $\mathrm{pH}$ adjustment at 7.0 with sodium hydroxide $0.1 \mathrm{M}$. Pathogenic bacteria were killed, and clear FFSs were obtained in both probiotic films and SEFs. Bottles were stirred and heated on a Heidolph magnetic stirrer for $15 \mathrm{~min}$ at $80^{\circ} \mathrm{C}$. The heated FFSs were cooled at $39^{\circ} \mathrm{C}$ and retained isothermally to avoid gelatin setting point until inoculation with probiotics. Three pellets of L. casei (corresponding to ca. $10 \mathrm{log}$ $\mathrm{CFU} / \mathrm{g}$ of film-forming solution-dry basis) were added to each FFSs $(100 \mathrm{~mL})$ and degassed using a vacuum pump at $40{ }^{\circ} \mathrm{C}$ for $10 \mathrm{~min}$. Then, $45 \mathrm{~g}$ of FFS was aseptically transferred using a serologic pipette and cast to Perspex plates $\left(20 \times 20 \mathrm{~cm}^{2}\right)$ fitted with a square frame around the edge to yield a $16 \times 16 \mathrm{~cm}^{2}$ film-forming area. The cast solutions were air-dried at $37^{\circ} \mathrm{C}$ for $15 \mathrm{~h}$ in a ventilated incubator to obtain films that could easily be peeled off. After drying, the films were peeled and conditioned at room temperature $\left(25 \pm 1{ }^{\circ} \mathrm{C}\right)$ or chilled at $4 \pm 1{ }^{\circ} \mathrm{C}$ under controlled relative humidity conditions ( $\left.54 \% \mathrm{RH}\right)$ in desiccators containing saturated magnesium nitrate solution [37].

\subsection{Microbiological Analysis}

To assess DFG's effect on the viability of probiotics and to compare this effect with those of BG (a mammalian source) and FG (a mammalian alternative gelatin source), a method described by Soukoulis et al. [38] was used with minor modification. The number of viable $L$. casei in the PGFs was evaluated. The number of live $L$. casei in the SEFs was measured every 7 days of storage at 4 and $25^{\circ} \mathrm{C}$ in FFSs and compared with the initial amount in films.

To determine the initial number of live probiotics in FFSs, $1 \mathrm{~mL}$ of film sample from each of FFS was suspended and vortexed in sterile PBS for half a minute to ensure thorough mixing. For PGFs, $1 \mathrm{~g}$ of each film sample was moved to $9 \mathrm{~mL}$ of sterile PBS. Then, individual pieces were left for hydration and then dissolved under constant agitation in an incubator at $37^{\circ} \mathrm{C}$ for $1 \mathrm{~h}$. To determine the effect of edible films without probiotics, the edible films were completely dissolved until no residual insoluble material was rec- 
ognizable. By using PBS, the obtained solutions were subjected to serial dilutions. Every dilution was pour-plated on MRS agar (Oxoid Ltd., Basingstoke, UK), and the plates were kept for $72 \mathrm{~h}$ at $37^{\circ} \mathrm{C}$ under anaerobic situations. Bacteria enumeration on agar plates was accomplished in triplicates by colony counting. All viable bacteria counts were expressed as $\log$ colony-forming units per gram (log $\mathrm{CFU} / \mathrm{g}, \mathrm{CFU} / \mathrm{g}=\mathrm{CFU} /$ plate dilution factor). The survival rate of the bacteria throughout the film-forming solution-drying procedure was obtained according to the following equation:

$$
\% \text { Viability }=\frac{N}{N_{0}} \times 100
$$

where $N_{0}$ and $N$ represent the numbers of viable bacteria before and after the implemented drying process, respectively [16].

L. casei inactivation upon storage data was expressed as the value of the relative viability fraction $N / N_{0}$. The viability data were fitted to a first-order reaction kinetics model, as described by the following equation:

$$
\frac{N_{t}}{N_{0}}=1-k_{T} t \text { Equation }
$$

where:

$N_{0}$ represents the initial number of viable bacteria

$N_{t}$ is the number of viable bacteria after a specific storage time (in CFU/g)

$t$ is the storage time (in a day)

$k_{T}$ is the inactivation rate constant at $T$ temperature $\left(\right.$ day $\left.^{-1}\right)$.

\subsection{Physicochemical Properties}

Analysis of the SEFs was performed after film conditioning in a desiccator containing saturated salt at a relative humidity of $54 \%$ and temperature of $25^{\circ} \mathrm{C}$ for 3 days.

\subsubsection{Thickness and Moisture Content (MC)}

Film thickness was measured by using a hand-held micrometer with an accuracy of $0.001 \mathrm{~mm}$ (thickness gauge; Ozaki MFG Co., Tokyo, Japan). Five measurements were taken from random samples and used to determine the average thickness.

The $M C$ was measured using the method described by Li, Ma, Ji, Sameen, Ahmed, Qin, Dai, Li, and Liu [22] with slight modification and calculated according to the following equation:

$$
\operatorname{MC}(\%)=\frac{m_{1}-m_{2}}{m_{1}} \times 100
$$

where $m_{1}$ and $m_{2}$ are the initial and final weights of the SEFs, respectively.

\subsubsection{Water Solubility (WS) and Swelling Ratio (SR)}

Film specimens $(2 \mathrm{~cm} \times 2 \mathrm{~cm})$ desiccated by $\mathrm{P}_{2} \mathrm{O}_{5}$ for 7 days were used for both measurements. The WS was determined based on the method described by Singh, Magalhães, Alves, Antunes, Miguel, Lindman, and Medronho [19] with slight modification. The samples were weighed $\left(W_{0}\right)$ and immersed in $80 \mathrm{~mL}$ of deionized water $(18 \mathrm{M} \Omega)$ at $35 \pm 1{ }^{\circ} \mathrm{C}$ under $50 \mathrm{rpm}$ agitation for $1 \mathrm{~h}$. Unresolved SEFs were dried to a constant weight $\left(W_{1}\right)$ at $60^{\circ} \mathrm{C}$. The WS was expressed in the following the equation:

$$
\text { WS }(\%)=\frac{w_{0}-w_{1}}{w_{0}} \times 100
$$

The $S R$ was measured according to the method of Abedinia, Ariffin, Huda, and Nafchi [32] with slight modification. Dried specimens were weighed as initial dry matter $\left(W_{1}\right)$, immersed in $30 \mathrm{~mL}$ of distilled water, and kept at $25^{\circ} \mathrm{C}$ for $2 \mathrm{~h}$. The surplus water on 
the surface was removed by using a filter paper. Afterward, the samples were weighed immediately $\left(W_{2}\right)$. The $S R$ was calculated according to the following equation:

$$
S R=(\%)=\frac{w_{2}-w_{1}}{w_{1}} \times 100
$$

Experiments were performed in five replicates, and the average was reported as the $S R$ value.

\subsubsection{Color and Opacity Properties}

Applying a Minolta colorimeter (Chroma Meter CR-400/410, Konica Minolta, Japan), color parameters were determined at three different areas of the sample's surface after calibration by using a white plate $\left(L^{*}=93.58, a^{*}=-0.88\right.$, and $\left.b^{*}=0.46\right)$. The color was recorded by using CIE- $L^{*} a^{*} b^{*}$ uniform color space (CIE-Lab), where $L^{*}$ demonstrates lightness, $a^{*}$ shows hue on a green $(-)$ to red $(+)$ axis, and $b^{*}$ exposes the hue on a blue $(-)$ to yellow (+) axis. The total color differentiation $\Delta E^{*}$ between the control sample (film without prebiotics) and SEFs was counted using the following equation:

$$
\Delta E^{*}=\sqrt{\left(\Delta L^{*}\right)^{2}+\left(\Delta a^{*}\right)^{2}+\left(\Delta b^{*}\right)^{2}}
$$

Opacity measurements were obtained based on the method devised by Soukoulis, Behboudi-Jobbehdar, Macnaughtan, Parmenter, and Fisk [16] using a UV-VIS spectrophotometer (Jenway Ltd., Stone, UK). The absorbance at $550 \mathrm{~nm}\left(A_{550}\right)$ was calculated, and film opacity was obtained based on the following formula:

$$
\text { Opacity value }=\frac{A_{550}}{\text { Thickness }}
$$

where the thickness is expressed in $\mathrm{mm}$.

\subsubsection{Water-Vapor Permeability (WVP)}

The gravimetrically ASTM E96-16 standard method was applied to determine WVP at $22 \pm 1{ }^{\circ} \mathrm{C}$. Weight loss versus time was plotted to obtain the slope $\left(\mathrm{r}^{2} \geq 0.99\right)$. The WVP of the film was calculated by Equation (8).

$$
W V P\left(g m^{-1} s^{-1} P^{-1}\right)=\frac{W V T R \times L}{\Delta P}
$$

where:

WVTR is the rate of water-vapor transmission $\left(\mathrm{g} / \mathrm{m}^{2} \mathrm{~s}^{1}\right)$ through film,

$L$ is the average film thickness (m),

$\Delta P$ is the partial water-vapor pressure difference $(\mathrm{Pa})$ between the two sides of the film. Three measurements were made for each film, and the mean value was reported.

\subsubsection{Prevention against Oxidation (PAO)}

According to the method described by Akman et al. [39], the PAO of the SEFs was measured indirectly with slight modification. Samples were conditioned at $25{ }^{\circ} \mathrm{C}, 55 \% \mathrm{RH}$ for $72 \mathrm{~h}$. Free antioxidant $(10 \mathrm{~mL})$, namely, fresh and refined sunflower oil, was poured into the cup and completely covered by each film and stored for 45 days inside an incubator at $25 \pm 1{ }^{\circ} \mathrm{C}$ and $55 \% \mathrm{RH}$. The oil peroxide values (PVs) were determined by using the method described by AOCS [40] and reported as the PAO index.

\subsection{Mechanical Properties of SEFS}

The mechanical properties were measured according to ASTM D882-16 with minor modification by applying a texture analyzer (TA.XT2i Texture Analyzer; Stable Micro 
Systems, Godalming, Surrey) equipped with a $30 \mathrm{~kg}$ load cell. The tests included the evaluation of tensile strength (TS), Young's modulus (YM), and elongation at break (EB).

\subsection{Scanning Electron Microscopy (SEM) of SEFs}

The microstructure of films was studied by SEM (Everhart-Thornley detector (FESEM-ETD) with QUANTA FEG 6502012 SEM system, FEI, Hillsboro, OR, USA). To facilitate SEM measurements, the samples with dimensions of $1 \mathrm{~cm} \times 1 \mathrm{~cm}$ from each film were coated with chromium, and their surface morphology was determined with an accelerating voltage of $5.0 \mathrm{kV}$.

\subsection{Statistical Analysis}

Statistical analyses were performed by statistical software package SPSS Version 24 (IBM Corp., Armonk, NY, USA). To determine the significant effects of prebiotics on physicochemical and mechanical properties of SEFs, the obtained experimental data were subjected to one-way analysis of variance (ANOVA) followed by an analysis of the comparison of means by using Duncan's post hoc method. The significance level was $p<0.05$.

\section{Results and Discussions}

\subsection{Effect of Gelatin Origin on the Storage Stability of L. casei}

The purpose of this evaluation was to compare the ability of various gelatins (DFG, $\mathrm{BG}$, and FG) in film form to enhance the survival of L. casei at $25^{\circ} \mathrm{C}$. The inactivation curves of L. casei immobilized in three different types of gelatin are shown in Figure 1 and Table 1. As the curves show, DFG has the potential to keep L. casei alive.

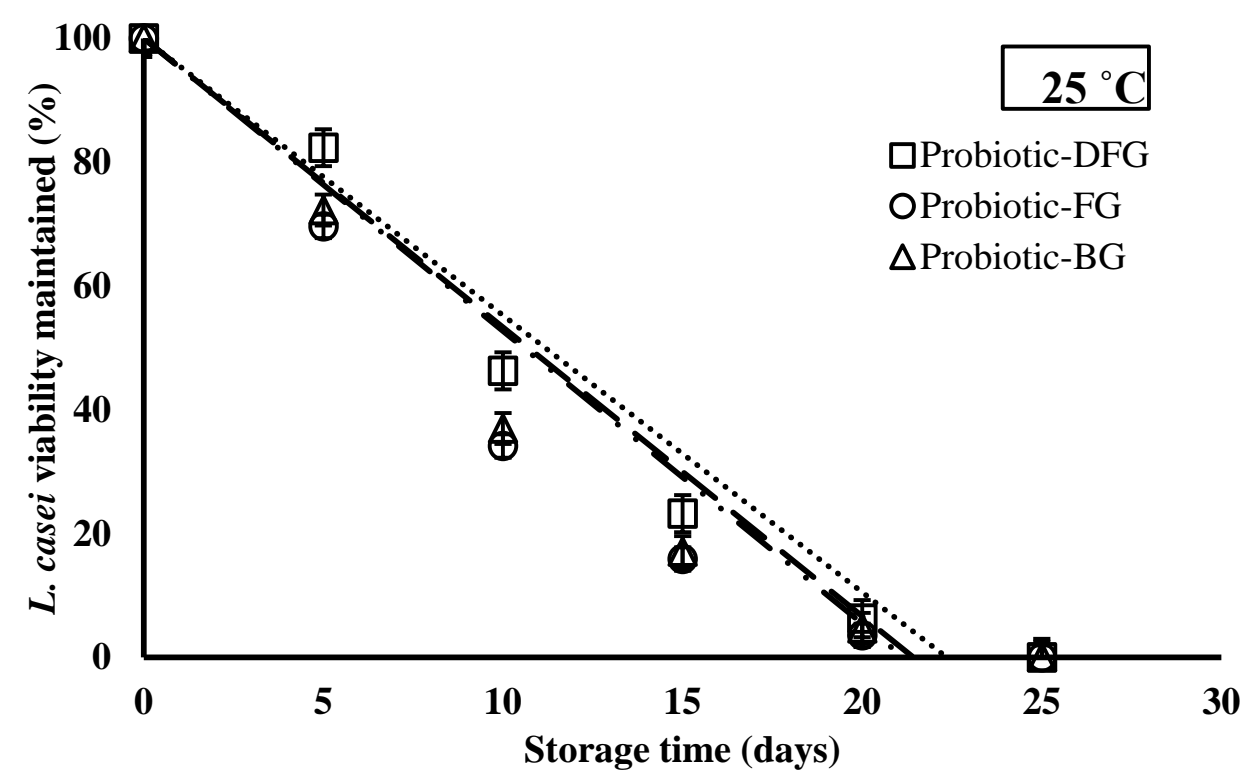

Figure 1. Inactivation curves of $L$. casei during storage at room temperature $\left(25^{\circ} \mathrm{C}\right)$ in different gelatin matrices for 25 days. DFG: Duck feet gelatin, FG: Fish gelatin, BG: Bovine gelatin.

Dong et al. [41] declared that one of the reasons for the inactivation of the live probiotics encapsulated in the biopolymer matrix is the matrix structure; physical structure can lead to the molecular mobility of the solvent throughout the matrix. Soukoulis et al. [42] evaluated the L. rhamnosus GG stability in binary starch-protein edible films. The gelatin showed the highest protection against osmotic and heat stress-induced injuries during drying, particularly in rice-based films. Proteins can increase probiotic survival by supplying micronutrients and scavenging free radicals (such as amino acids and peptides) that are essential for improving the weak growth of proteolytic probiotic bacteria $[43,44]$. The 
imino acid contents (proline + hydroxyproline) of gelatin stabilize the structure by forming hydrogen bonds. The hydroxyproline content of DFG is higher than that of mammalian and chicken gelatins [27]. Table 1 shows that the shelf-life of bacteria in DFG gelatin matrix was higher than in the other two gelatins, but the difference was not statistically significant. The results of this experiment indicated that DFG had good potential for immobilizing bacteria and was a good option as a film synbiotic.

Table 1. Inactivation rates of L. casei immobilized in plasticized gelatin matrices (probiotic films) stored under room temperature condition.

\begin{tabular}{cccc}
\hline Probiotic Film & $\mathbf{k ~ 2 5}{ }^{\circ} \mathbf{C}\left(\mathbf{\%} / \mathbf{d a y}^{\mathbf{- 1}}\right)$ & Estimated Shelf-Life at $\mathbf{2 5}{ }^{\circ} \mathbf{C}$ (day) & $\mathbf{R}^{\mathbf{2}}$ \\
\hline Probiotic-DFG & $4.47 \pm 0.12^{\mathrm{a}}$ & 20.11 & 0.957 \\
Probiotic-BG & $4.66 \pm 0.12^{\mathrm{a}}$ & 19.27 & 0.908 \\
Probiotic-FG & $4.72 \pm 0.12^{\mathrm{a}}$ & 19.03 & 0.887 \\
\hline
\end{tabular}

a The same letter indicates no significantly different values $(p>0.05)$ according to Duncan's post hoc meanscomparison test. Data are presented as mean $\pm \mathrm{SD}(n=3)$. Shelf-life mentions to the time needed to induce the fate of the $90 \%$ of total viable cells of $L$. casei. DFG: Duck feet gelatin, FG: Fish gelatin, BG: Bovine gelatin.

\subsection{Color Properties and Morphology}

In the present study, homogeneous and flexible films were obtained after drying at $25{ }^{\circ} \mathrm{C}$ and $55 \% \mathrm{RH}$. Results of measurement of the appearance properties provide information about the films' intended application but not the chemical reaction. Film transparency is the key to solving the problem of good film acceptance by end-users when the film is used to cover or improve the food surface. Table 2 shows the optical and color properties of edible bioactive films. It shows that the addition of prebiotic fiber was associated with a detectable decrease $(p<0.05)$ of the transparency (or increase in opacity) of the edible films compared with those that only contain DFG. This observation was in accordance with the results of Soukoulis et al. [45] and Wu et al. [46].

Table 2. Optical and color properties of edible synbiotic films containing L. casei and different types of prebiotic fibers.

\begin{tabular}{cccccc}
\hline Synbiotic Film & $\mathbf{L}^{*}$ & $\mathbf{a}^{*}$ & $\mathbf{b}^{*}$ & $\Delta^{*}$ & Opacity Values $^{*}$ \\
\hline Control & $95.35 \pm 0.07^{\mathrm{a}}$ & $-0.39 \pm 0.01^{\mathrm{d}}$ & $3.42 \pm 0.01^{\mathrm{e}}$ & - & $0.82^{\mathrm{a}} \pm 0.04^{\mathrm{c}}$ \\
Syn-DFG/Dex & $94.17 \pm 0.08^{\mathrm{c}}$ & $-0.05 \pm 0.003^{\mathrm{a}}$ & $4.41 \pm 0.01^{\mathrm{c}}$ & $3.9 \pm 0.02^{\mathrm{c}}$ & $1.79 \pm 0.15^{\mathrm{b}}$ \\
Syn-DFG/GA & $94.59 \pm 0.08^{\mathrm{b}}$ & $-0.33 \pm 0.02^{\mathrm{c}}$ & $4.78 \pm 0.05^{\mathrm{b}}$ & $4.33 \pm 0.06^{\mathrm{b}}$ & $3.94 \pm 0.11^{\mathrm{a}}$ \\
Syn-DFG/Poly $^{\mathrm{a}}$ & $94.51 \pm 0.1^{\mathrm{b}}$ & $-0.74 \pm 0.03^{\mathrm{e}}$ & $6.24 \pm 0.08^{\mathrm{a}}$ & $5.74 \pm 0.1^{\mathrm{a}}$ & $3.24 \pm 0.08^{\mathrm{a}}$ \\
Syn-DFG/SS $^{\mathrm{b}}$ & $94.47 \pm 0.12^{\mathrm{b}}$ & $-0.25 \pm 0.02^{\mathrm{b}}$ & $3.80 \pm 0.04^{\mathrm{d}}$ & $3.32 \pm 0.07^{\mathrm{d}}$ & $1.92 \pm 0.12^{\mathrm{b}}$ \\
\hline
\end{tabular}

${ }^{a-e}$ Different letters between rows indicate significantly different values $(p<0.05)$ according to Duncan's post hoc means-comparison test. Data are presented as mean \pm SD $(n=3)$. Duck feet gelatin, Dex: Dextrin, GA: gum Arabic, Poly: polydextrose, SS: sago starch.

Significant differences in the luminosity $\left(L^{*}\right)$ of the SEFs $(p<0.05)$ were observed. The control sample and Syn-DFG/Dex film exhibited the highest and lowest luminosity, respectively, and no significant differences were observed among gum GA, Poly, and Syn films. When prebiotics were added, significant differences in $a^{*}$ and $b^{*}$ were observed in all SEFs. Syn-DFG/Poly exhibited the highest scores for green and yellow color components, whereas Syn-DFG/Dex and control showed the highest values for red and blue hue color components $\left(a^{*}\right.$ and $\left.b^{*}\right)$, respectively.

$\Delta E^{*}$ results indicated that in all cases, $\Delta E^{*}$ values were higher than 3 , which was assumed to be the threshold of human-perceivable color difference [26]. Syn-DFG/SS had the lowest color divergence from the control, whereas Syn-DFG/Poly had the highest. Thus, according to the results, opacity and color differences with significant probability could be attributed to prebiotic fiber presence and type. The results are shown in Figure 2. 

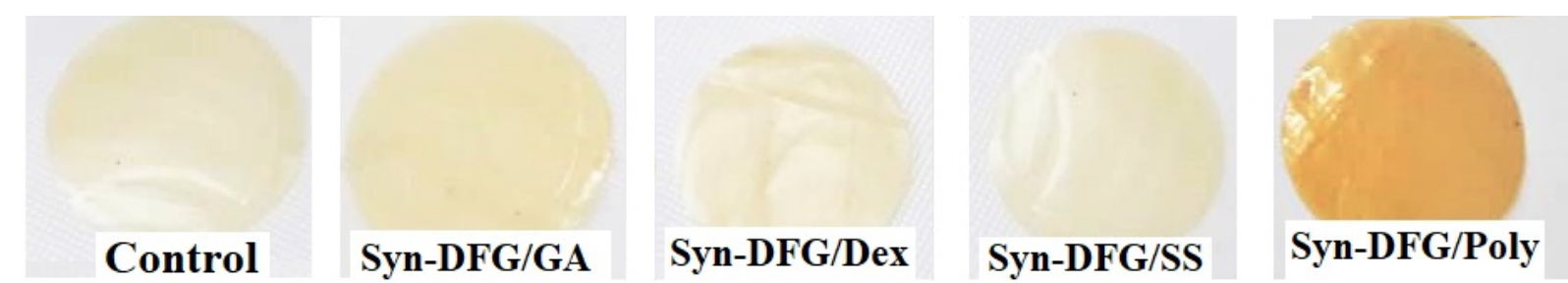

Figure 2. Appearance of probiotic and synbiotic films. Duck feet gelatin, Dex: Dextrin, GA: gum Arabic, Poly: polydextrose, SS: sago starch.

The SEM microscopic analysis of the SEFs (Figure 3) indicated that the addition of prebiotic fibers in the DFG film leads to noticeable changes in the microstructure of the SEFs. SEM micrographs show that blending the prebiotic fiber with gelatin before film formation leads to a more uniform and compact structure with no noticeable micropores or interspaces. Prebiotics act as fillers of the interspaces of entangled gelatin network. L. casei cells on the probiotic edible film surfaces were not identified (data not shown). The extensive coverage and properties of bacterial cells in SEFs were better than those in gelatin only. No remarkable differences between the structural conformations of the films comprising Dex, GA, Poly, and SS were detected, as mentioned by previous researchers [16,47].
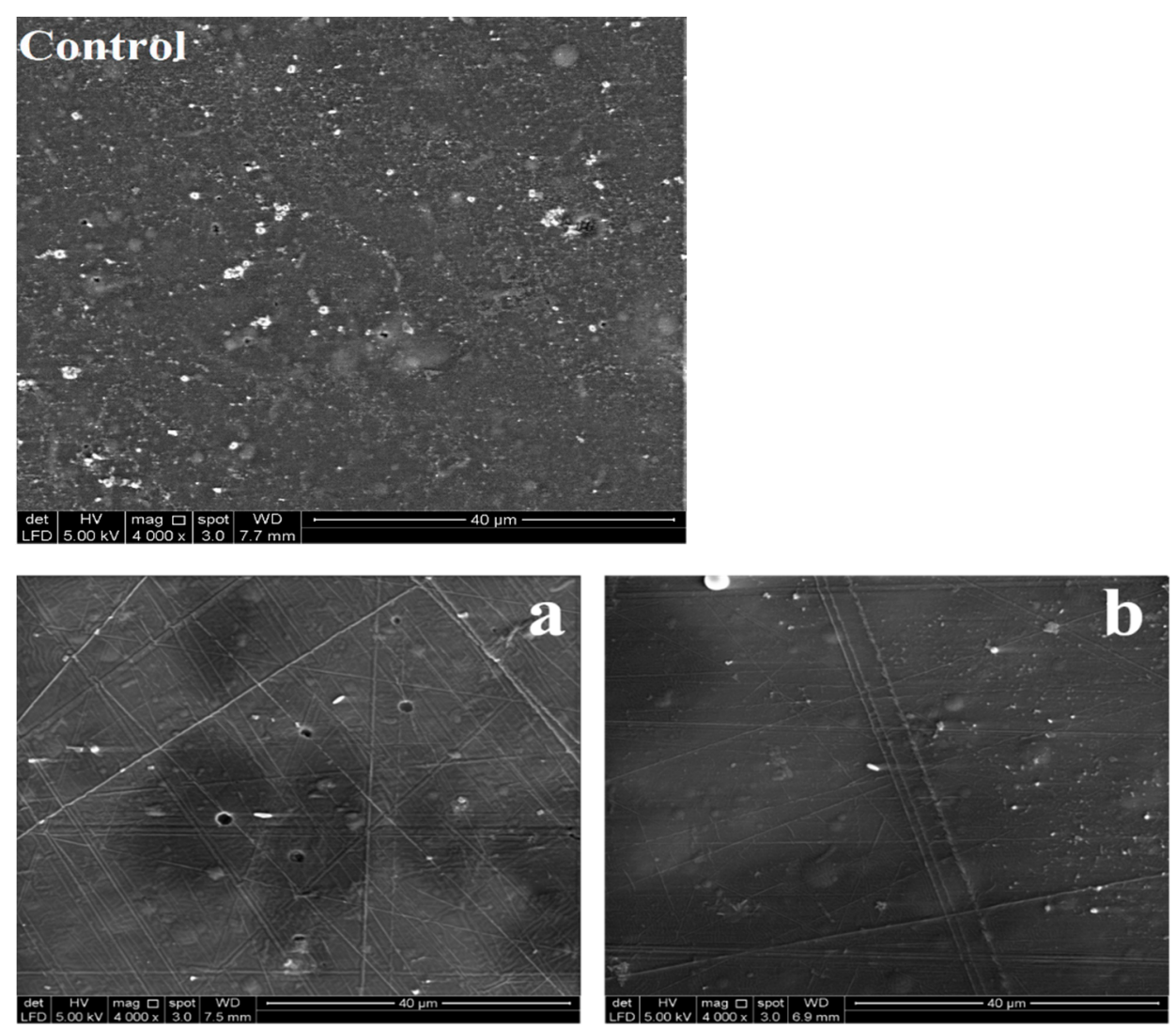

Figure 3. Cont. 

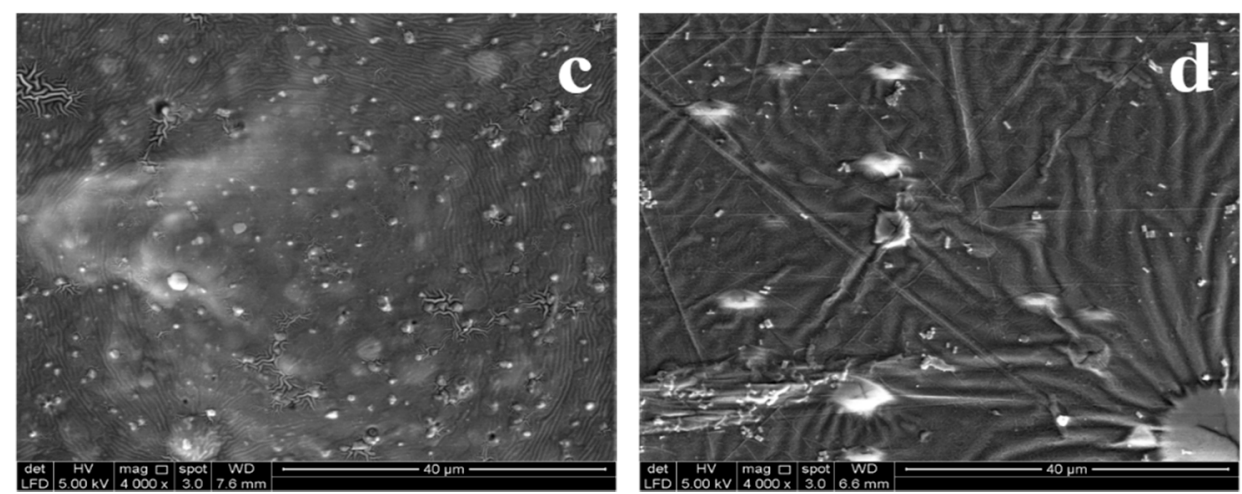

Figure 3. Surface SEM visualization of the probiotic and synbiotic edible films containing L. casei. (a) Syn-DFG/SS, (b) Syn-DFG/GA, (c) Syn-DFG/Dex, and (d) Syn-DFG/Poly.

The Syn-DFG/SS and Syn-DFG/GA showed a more nonporous, smooth, and uniform structure than the Poly and Dex films. However, in all cases, prebiotics application resulted in good miscibility and compatibility with gelatin, possibly through hydrogenbond interactions, because no phase aggregation or separation phenomena were observed. Further studies are needed to completely characterize the phase compatibility within the biopolymers, as this topic was not among the initial objectives of this research.

\subsection{Effect of Prebiotics on the Storage Stability of L. casei}

In Figure 4, the inactivation curves of L. casei immobilized in SEFs are presented. As expected, the inactivation rates (Table 3 ) of $L$. casei were considerably higher $(p<0.05)$ in the systems preserved at room temperature. Keeping the SEFs at $25{ }^{\circ} \mathrm{C}$ in the presence of GA and Dex in the plasticized matrices improved the storage stability of L. casei. Moreover, SS and Poly had no significant effect on the improvement of $L$. casei. The synbiotic film containing GA had the highest estimated shelf-life values at both storage temperatures according to its ability to sustain L. casei, followed by Dex, Poly, and SS. The increase in storage temperature induced an almost four-fold acceleration of the inactivation rate of $L$. casei. Calame et al. [48] demonstrated that the numbers of Bifidobacteria and Lactobacilli 4 weeks after consumption were significantly higher for GA. One of the most promising applications related to GA is that it is relatively impossible for various enzymes in the small intestine to access it. Thus, GA is a prebiotic that can be categorized as nondigestible food. GAs are substances that contribute to the health of the host by selectively stimulating the growth and/or activity of one bacteria or a limited number of bacteria in the large intestines without stimulating unwanted bacteria.

Table 3. Inactivation rates of L. casei immobilized in plasticized synbiotic DFG and stored either in chilled or roomtemperature conditions.

\begin{tabular}{|c|c|c|c|c|c|c|}
\hline Synbiotic Film & $\begin{array}{c}\mathrm{k} 4^{\circ} \mathrm{C} \\
\left(\% / \text { day }^{-1}\right)\end{array}$ & $\begin{array}{l}\text { Estimated Shelf- } \\
\text { Life }{ }^{*} \text { at } 4{ }^{\circ} \mathrm{C}\end{array}$ & $\mathbf{R}^{2}$ & $\begin{array}{c}\mathrm{k} 25^{\circ} \mathrm{C} \\
\left(\% / \text { day }^{-1}\right)\end{array}$ & $\begin{array}{c}\text { Estimated Shelf- } \\
\text { Life at } 25^{\circ} \mathrm{C}\end{array}$ & $\mathbf{R}^{2}$ \\
\hline Control & $1.14 \pm 0.09^{c}$ & 78 & 0.95 & $4.49 \pm 0.12^{b}$ & 20 & 0.95 \\
\hline Syn-DFG/Dex & $0.9 \pm 0.05^{b}$ & 99 & 0.96 & $3.33 \pm 0.08^{a}$ & 27 & 0.97 \\
\hline Syn-DFG/Poly & $0.9 \pm 0.03^{b}$ & 99 & 0.97 & $4.28 \pm 0.05^{b}$ & 21 & 0.97 \\
\hline Syn-DFG/GA & $0.8 \pm 0.04^{\mathrm{a}}$ & 111 & 0.97 & $3.1 \pm 0.07^{\mathrm{a}}$ & 29 & 0.99 \\
\hline Syn-DFG/SS & $0.95 \pm 0.08^{b}$ & 94 & 0.95 & $4.31 \pm 0.11^{b}$ & 21 & 0.97 \\
\hline
\end{tabular}

${ }^{a-c}$ Different letter between rows indicate significantly different values $(p<0.05)$ according to Duncan's post hoc means-comparison test.

Data are presented as mean $\pm \operatorname{SD}(n=3)$. * Shelf-life mentions to the time needed to induce the fate of the $90 \%$ of total viable cells of L. casei. 

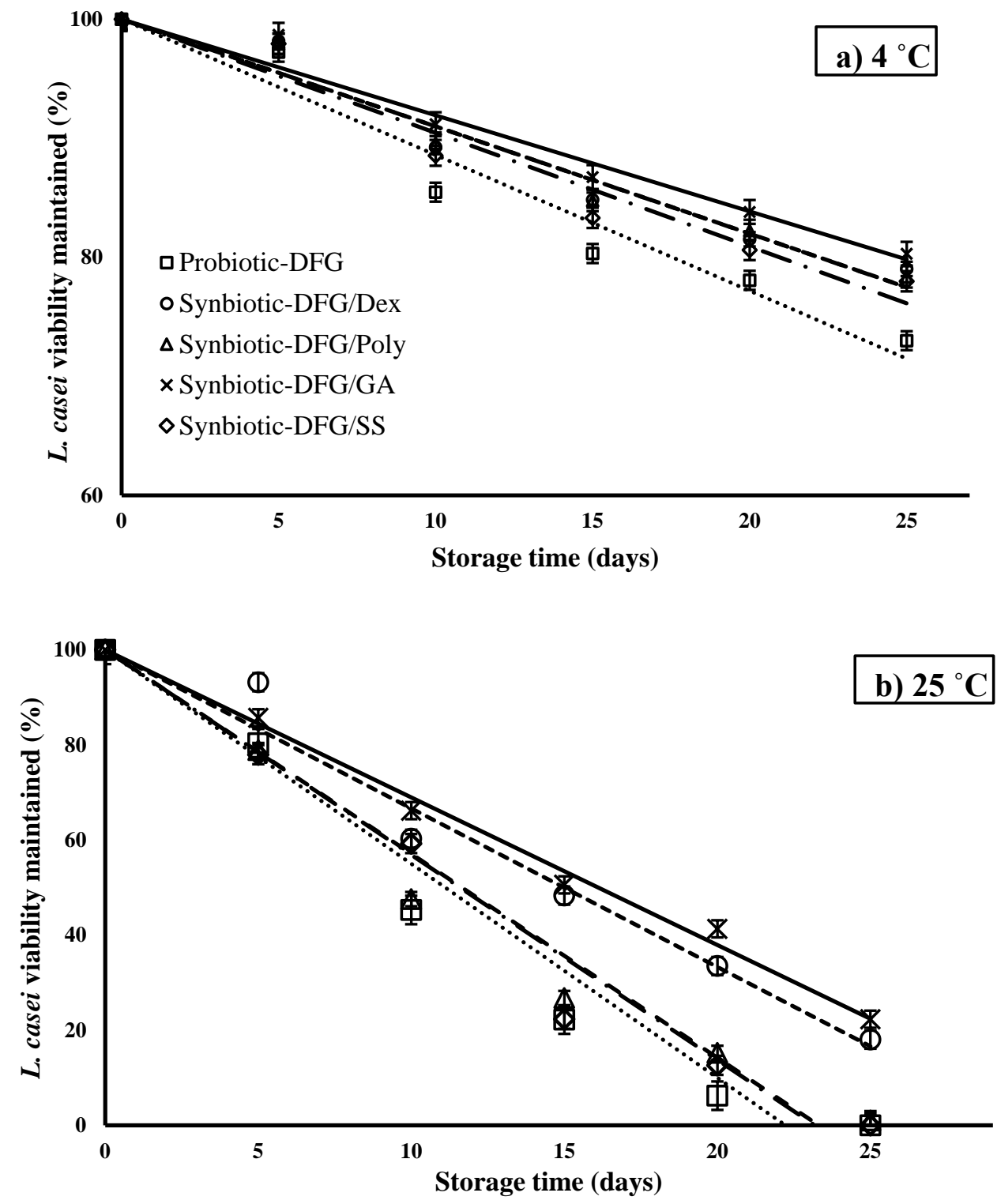

Figure 4. Inactivation curves of $L$. casei trapped in synbiotic edible films during storage: (a) under chilled conditions $\left(4^{\circ} \mathrm{C}\right)$ and $(\mathrm{b})$ under room temperature conditions $\left(25^{\circ} \mathrm{C}\right)$ for 25 days.

The estimated shelf-life of the SEFs (in terms of L. casei survival) was in the range of 78-111 and 20-29 days for the systems preserved under 4 and $25^{\circ} \mathrm{C}$ conditions, respectively (Table 3). External factors, such as oxygen, water activity, and temperature, are known to negatively affect the viability of living probiotic cells. In the case of intermediate moisture systems that contain edible films, the presence of high amounts of solutes together with the rubbery physical state (solutes improved molecular mobility) facilitates the occurrence of chemical and enzymatic reactions that destroy essential cellular structures, e.g., phospholipid membrane bilayers [49]. Therefore, using low $M C$ matrices with low permeability to gases comprising free radical scavenging agents (to control lipid oxidation of cellular membranes) is a proficient strategy for increasing probiotic viability in food systems [50]. Generally, the prebiotic film constancy at room temperature is comparable to that of anhydrobiotics, e.g., spray-dried powders, under the same relative humidity conditions [51].

A complete mechanistic understanding of probiotics stability is not available in biopolymer matrices during storage. However, factors such as steric hindrance of solutes, the translational matrix diffusion of oxygen, the presence of nutrients and free radical 
scavenging agents, and the interaction via hydrogen bonding with the polar head groups of membranes phospholipids can possibly contribute to the stability of probiotics in prebiotic films [52,53].

\subsection{Effect of Prebiotics on Physicochemical Properties of SEFs}

Table 4 shows the results for thickness, MC (moisture content), SR (percentage of water gained [g]/total solids [g]), and WS (percentage of soluble solids [g]/total solids [g]) of SEFs. With the addition of prebiotics to DFG, a considerable $(p<0.05)$ increase was found in film thickness. Except for GA, the type of prebiotics did not considerably affect the thickness of the edible films. However, a difference was observed between the DFG only films and the others. Our findings are in agreement with those of Soukoulis, Singh, Macnaughtan, Parmenter and Fisk [42], Galus et al. [54], and Fakhouri et al. [55].

Table 4. Physicochemical properties of synbiotic edible films.

\begin{tabular}{ccccc}
\hline Synbiotic Film & Thickness (mm) $^{\text {MC (\%) }}$ & SR (\%) & WS (\%) \\
\hline Control & $0.17 \pm 0.01^{\mathrm{c}}$ & $10.15 \pm 0.1^{\mathrm{b}}$ & $662.1 \pm 13.2^{\mathrm{a}}$ & $19.37 \pm 1.12^{\mathrm{c}}$ \\
Syn-DFG/Dex & $0.21 \pm 0.05^{\mathrm{a}}$ & $9.88 \pm 0.21^{\mathrm{b}}$ & $444.34 \pm 10.1^{\mathrm{c}}$ & $18.08 \pm 0.95^{\mathrm{c}}$ \\
Syn-DFG/Poly & $0.21 \pm 0.02^{\mathrm{a}}$ & $10.64 \pm 0.15^{\mathrm{b}}$ & $675.55 \pm 19.8^{\mathrm{a}}$ & $44.07 \pm 1.4^{\mathrm{a}}$ \\
Syn-DFG/GA $^{\mathrm{b}}$ & $0.19 \pm 0.01^{\mathrm{b}}$ & $10.19 \pm 0.11^{\mathrm{b}}$ & $602.34 \pm 9.2^{\mathrm{b}}$ & $29.49 \pm 0.78^{\mathrm{b}}$ \\
Syn-DFG/SS & $0.21 \pm 0.01^{\mathrm{a}}$ & $10.95 \pm 0.05^{\mathrm{a}}$ & $569.32 \pm 12.11^{\mathrm{b}}$ & $18.57 \pm 1.1^{\mathrm{c}}$ \\
\hline
\end{tabular}

In terms of MC, Syn-DFG/SS showed a significant difference (10.95\%) from the others. Water-vapor mass transfer through the film is the driving force of moisture distribution from the film. Prebiotic type did not exert significant influence on the $M C$ of samples. Generally, the concentration, structuring ability of the biopolymers, and water-holding capacity, combined with the amount and kind of plasticizing agents, are the main parameters influencing equilibrium moisture levels in edible films [16].

The MC of probiotic products is another factor influencing the shelf-life stability of live bacteria. Oxygen and moisture adversely affect bacterial survival. The amount of remaining water affects bacterial survival during drying and storage [56]. Braber, Vergara, Rossi, Aminahuel, Mauri, Cavaglieri, and Montenegro [50] suggested that molecular mobility of the matrix composition and moisture uptake features are better factors to consider for improving probiotic viability during storage.

The WS values found for DFG, Dex, and SS films $(19.37,18.08$, and 18.5\% g soluble solids /g total solids) were considerably lower than the values found for the GA and Poly films (29.49 and $44.07 \%$ g soluble solids/g total solids). This finding possibly reveals that Dex, SS, and control films are more resistant to dissolution in water than the others. The WS is one of the most significant properties investigated in food and pharmaceutical applications. Unlike water permeability, WS is characterized by chemical structure and defines the material tolerance or resistance to water. Therefore, stability in water was indicated. Lee et al. [57] stated that films could be used as covering materials to constrain exudation in frozen foods. The higher the WS results are, the more insufficient the stability of such films is. The $S R$ defines the amount of water absorbed by films. It reflects significant property features of carbohydrate and protein films, as these biopolymers primarily swell when suspended in water and show consequential structural changes. The SR has been used to represent the amount of crosslinking and is used in protein films based on collagen. In the current research, no significant differences $(p<0.05)$ in SR were observed among the Poly and the control films. The $S R$ values (444.34-675.55\%) were obtained. Blended GA and SS had significant $(p<0.05)$ differences with the control, and Dex films showed the lowest $S R$. 


\subsection{Effect of Prebiotics on WVP and PAO of SEFs}

The films' WVP was in the range of 2.74-3.37 $\left(\times 10^{-11} \cdot \mathrm{g} \cdot \mathrm{m}^{-1} \cdot \mathrm{Pa}^{-1} \cdot \mathrm{s}^{-1}\right)$, thereby showing that the differences depended on the type of prebiotic added. As shown in Figure 5, the addition of all prebiotics except $\mathrm{SS}$ was associated with a significant reduction in $W V P(p<0.05)$. The highest amount of WVP was observed in SS, and the lowest was found in Dex films. The nature of each prebiotic can be the main cause of this discrepancy. The concentrations of prebiotics, gelatin, and glycerol were the same in the films. Thus, the main reason for the difference in the WVP was the nature and type of prebiotics. Ebrahimi, Mohammadi, Rouhi, Mortazavian, Shojaee-Aliabadi, and Koushki [17] stated that external factors, such as $W V P$, under normal storage conditions affect immobilized probiotic survival of bacteria in the film structure. Other factors, such as hydrophobicity ratio, crystalline and amorphous ratio, film thickness, and integrity, are also mentioned as practical factors. Adding L. casei to DFG film reduced the WVP from 5 in our previous study [32] to $3.37\left(\times 10^{-11} . \mathrm{g} . \mathrm{m}^{-1} \cdot \mathrm{Pa}^{-1} \cdot \mathrm{s}^{-1}\right)$. In general, the difference in $W V P$ is directly related to the affinity of film for water; in particular, the weak inhibitory properties of gelatin films affect their tendency to have high water content (Table 4). The lowest amount of $W V P$ was observed with the lowest amount of MC (Syn-DFG/Dex), thereby showing that dextrin's ability to reduce the intermolecular space creates hydrogen bonds with gelatin and ultimately reduces water mobility and WVP.

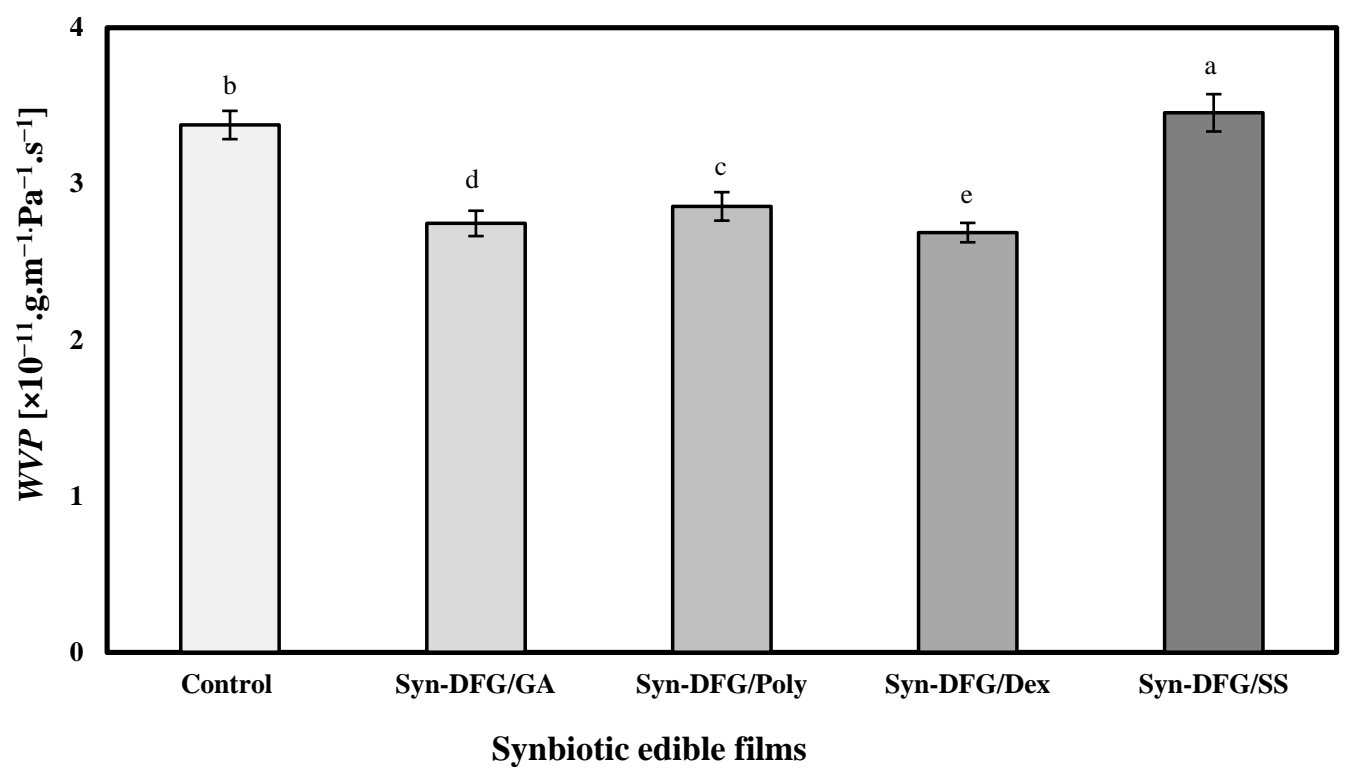

Figure 5. Water-vapor permeability of synbiotic edible films. a-e: Different letters on each column indicate significantly different values $(p<0.05)$ following Duncan's post hoc means-comparison test.

The PAO was expressed through SEFs based on the PV. The PV in Figure 6 shows that the PV films varied from 5.01 to $15.41 \mathrm{meq} / \mathrm{kg}$ oil compared with the control sample (14.46 meq $/ \mathrm{kg}$ oil). All combinations of prebiotics, except sago starch, caused a significant reduction $(p<0.05)$ in PV. However, the amount of PV in the SS film was higher than the control, but no statistically significant difference was found $(p>0.05)$. The presence of oxygen around probiotic bacteria can cause toxic metabolites in cells, leading to oxidative stress, damage, and cell death. Therefore, oxygen and its derivatives are effective factors that determine the survival of probiotics [58]. Thus, films that showed the least PAO provided better protective effect for $L$. casei. 


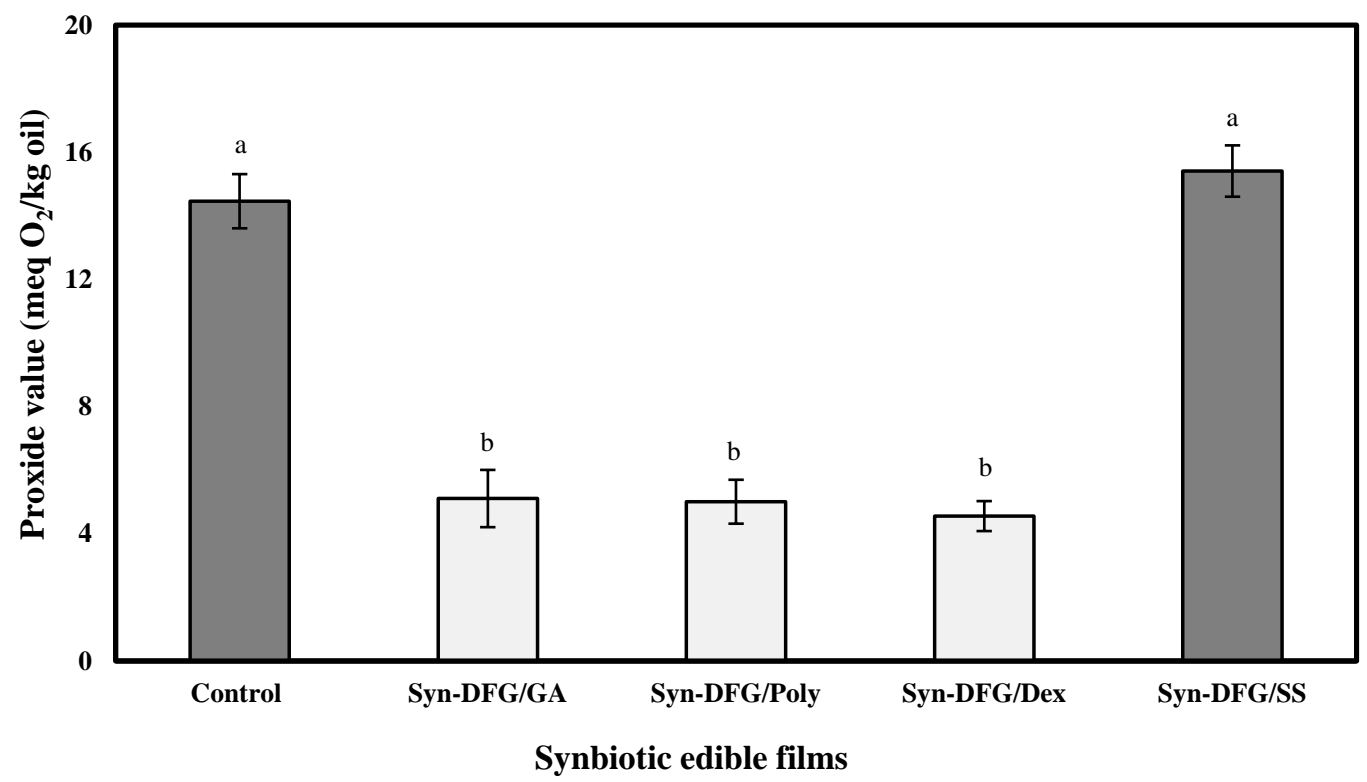

Figure 6. Prevention against oxidation of synbiotic edible films. a-b: Different letters on each column indicate significantly different values $(p<0.05)$ following Duncan's post hoc means-comparison test.

\subsection{Mechanical Properties of SEFs}

Mechanical characterization of synbiotic films (Table 5) showed that Dex film had the highest TS (18.36 MPa), followed by GA (18.2 MPa), but these results did not have a significant difference of $5 \%$ with the control sample $(16.81 \mathrm{MPa})$ and had a significant difference $(p<0.05)$ with the SS and Poly films. The control sample did not show any difference with the SS film. The films showed EB values ranging between $25.93 \%$ for SynDFG/Dex and $94.64 \%$ for Syn-DFG/Poly films. No statistically significant difference was found between GA and SS films for elongation values, but these films showed significant differences with the control.

Table 5. Mechanical properties including of tensile strength (TS), elongation at break (EB), and Young's modulus (YM) of synbiotic DFG films.

\begin{tabular}{cccc}
\hline Synbiotic Film & TS $\mathbf{( M P a )}$ & EB (\%) & YM (MPa) \\
\hline Control & $17.1 \pm 2.2^{\mathrm{ab}}$ & $31.3 \pm 1.2^{\mathrm{c}}$ & $516.81 \pm 11.2^{\mathrm{ab}}$ \\
Syn-DFG/Dex & $18.36 \pm 0.18^{\mathrm{a}}$ & $27.93 \pm 3.2^{\mathrm{c}}$ & $574.66 \pm 12.2^{\mathrm{a}}$ \\
Syn-DFG/Poly & $6.97 \pm 0.5^{\mathrm{c}}$ & $94.64 \pm 6.4^{\mathrm{a}}$ & $78.89 \pm 8.7^{\mathrm{c}}$ \\
Syn-DFG/GA & $18.2 \pm 0.2^{\mathrm{a}}$ & $49.53 \pm 4.1^{\mathrm{b}}$ & $407.2 \pm 10.2^{\mathrm{b}}$ \\
Syn-DFG/SS & $15.01 \pm 0.9^{\mathrm{b}}$ & $48.52 \pm 2.5^{\mathrm{b}}$ & $413.04 \pm 19.41^{\mathrm{b}}$ \\
\hline
\end{tabular}

$\overline{\mathrm{a}-\mathrm{c}}$ Different letters indicate significantly different values $(p<0.05)$ following Duncan's post hoc means-comparison test. Data are shown as mean $\pm \mathrm{SD}(n=3)$.

Table 5 shows that although the addition of dextrin did not significantly differ with the control in terms of EB, such an addition made the bioactive film more frangible. In the presence of other prebiotics, significant differences were found. The highest EB of $94.64 \%$ was observed in Poly films.

Espitia, Batista, Azeredo, and Otoni [1] confirmed that the addition of prebiotics affected the physical properties of the edible films, which showed impaired tensile strength and boosted extensibility compared with prebiotic-free films (control). In general, except for Syn-DFG/Poly, all of the prebiotics exhibited an acceptable mechanical characterization.

\section{Conclusions}

Films made from DFG could replace gelatin derived from mammals in the generation of bioactive films. The low moisture content of DFG films suggested that they can 
be a carrier of bioactive compounds, especially probiotics. This study showed that the microstructure of the obtained film from DFG could prevent water mobility, oxygen, and light from reaching the bacteria and can be a more suitable matrix for the probiotic carrier compared with bovine or fish gelatin films. The results of adding prebiotics showed that the gum arabic coatings and fillings were better than others and kept the bacteria alive for longer in two periods of time and at different temperatures.

Supplementary studies and suggestions are as follows:

- Several probiotic bacteria can be simultaneously used under the conditions of this study to evaluate the films' ability to keep bacteria alive.

- The application of bioactive Syn-DFG/GA film to ready-to-eat or processed-meat packaging needs to be investigated.

Author Contributions: A.A.: investigation, conceptualization, methodology, validation, formal analysis, and writing-original draft; A.M.N.: software, data curation, validation, and supervision; F.A. (Faezeh Alimohammadi): investigation; F.T.: investigation; N.R.: investigation; M.R.S.A.: investigation; F.A. (Fazilah Ariffin): conceptualization and funding; N.H.: investigation and resources; J.R.: formal analysis and writing — original draft. All authors have read and agreed to the published version of the manuscript.

Funding: This study was supported by Short-Term Grant [304PTEKIND/6315423], 2020, from Universiti Sains Malaysia and The APC was funded by Universiti Malaysia Sabah.

Institutional Review Board Statement: Not applicable.

Informed Consent Statement: Not applicable.

Data Availability Statement: The data presented in this study are available on request from the corresponding author.

Conflicts of Interest: The authors declare no conflict of interest.

\section{References}

1. Espitia, P.J.P.; Batista, R.A.; Azeredo, H.M.C.; Otoni, C.G. Probiotics and their potential applications in active edible films and coatings. Food Res. Int. 2016, 90, 42-52. [CrossRef]

2. Lopez-Santamarina, A.; Gonzalez, E.G.; Lamas, A.; Mondragon, A.d.C.; Regal, P.; Miranda, J.M. Probiotics as a Possible Strategy for the Prevention and Treatment of Allergies. A Narrative Review. Foods 2021, 10, 701. [CrossRef]

3. Hu, J.; Zhang, L.; Lin, W.; Tang, W.; Chan, F.K.L.; Ng, S.C. Review article: Probiotics, prebiotics and dietary approaches during COVID-19 pandemic. Trends Food Sci. Technol. 2020. [CrossRef]

4. Scalfaro, C.; Iacobino, A.; Nardis, C.; Franciosa, G. Galleria mellonella as an in vivo model for assessing the protective activity of probiotics against gastrointestinal bacterial pathogens. FEMS Microbiol. Lett. 2017, 364, fnx064. [CrossRef] [PubMed]

5. Dixon, A.; Robertson, K.; Yung, A.; Que, M.; Randall, H.; Wellalagodage, D.; Cox, T.; Robertson, D.; Chi, C.; Sun, J. Efficacy of Probiotics in Patients of Cardiovascular Disease Risk: A Systematic Review and Meta-analysis. Curr. Hypertens. Rep. 2020, 22, 1-27. [CrossRef]

6. Shoukat, S. Potential anti-carcinogenic effect of probiotic and lactic acid bacteria in detoxification of benzo [a] pyrene: A review. Trends Food Sci. Technol. 2020, 99, 450-459. [CrossRef]

7. Jäger, R.; Purpura, M.; Farmer, S.; Cash, H.A.; Keller, D. Probiotic Bacillus coagulans GBI-30, 6086 improves protein absorption and utilization. Probiotics Antimicrob. Proteins 2018, 10, 611-615. [CrossRef]

8. Moghaddam, M.F.T.; Jalali, H.; Nafchi, A.M.; Nouri, L. Evaluating the effects of lactic acid bacteria and olive leaf extract on the quality of gluten-free bread. Gene Rep. 2020, 21, 100771. [CrossRef]

9. Dhillon, P.; Singh, K. Therapeutic Applications of Probiotics in Ulcerative Colitis: An updated review. PharmaNutrition 2020, 13, 100194. [CrossRef]

10. Żółkiewicz, J.; Marzec, A.; Ruszczyński, M.; Feleszko, W. Postbiotics—A Step Beyond Pre-and Probiotics. Nutrients 2020, 12, 2189. [CrossRef]

11. Delvarianzadeh, M.; Nouri, L.; Nafchi, A.M.; Ebrahimi, H. Physicochemical, rheological, and sensory evaluation of voluminous breads enriched by purslane (Portulaca oleracea L.). Ital. J. Food Sci. 2020, 32, 815-830.

12. Chugh, B.; Kamal-Eldin, A. Bioactive compounds produced by probiotics in food products. Curr. Opin. Food Sci. 2020, $32,76-82$. [CrossRef]

13. Asadzadeh, A.; Jalali, H.; Azizi, M.H.; Mohammadi Nafchi, A. Production of oat bran functional probiotic beverage using Bifidobacterium lactis. J. Food Meas. Charact. 2020, 15, 1301-1309. [CrossRef] 
14. Pandhi, S.; Kumar, A.; Alam, T. Probiotic Edible Films and Coatings: Concerns, Applications and Future Prospects. J. Packag. Technol. Res. 2019, 3, 261-268. [CrossRef]

15. Piermaria, J.; Diosma, G.; Aquino, C.; Garrote, G.; Abraham, A. Edible kefiran films as vehicle for probiotic microorganisms. Innov. Food Sci. Emerg. Technol. 2015, 32, 193-199. [CrossRef]

16. Soukoulis, C.; Behboudi-Jobbehdar, S.; Macnaughtan, W.; Parmenter, C.; Fisk, I.D. Stability of Lactobacillus rhamnosus GG incorporated in edible films: Impact of anionic biopolymers and whey protein concentrate. Food Hydrocoll. 2017, 70, 345-355. [CrossRef]

17. Ebrahimi, B.; Mohammadi, R.; Rouhi, M.; Mortazavian, A.M.; Shojaee-Aliabadi, S.; Koushki, M.R. Survival of probiotic bacteria in carboxymethyl cellulose-based edible film and assessment of quality parameters. LWT Food Sci. Technol. 2018, 87, 54-60. [CrossRef]

18. Bekhit, M.; Arab-Tehrany, E.; Kahn, C.J.; Cleymand, F.; Fleutot, S.; Desobry, S.; Sánchez-González, L. Bioactive films containing alginate-pectin composite microbeads with Lactococcus lactis subsp. lactis: Physicochemical characterization and antilisterial activity. Int. J. Mol. Sci. 2018, 19, 574. [CrossRef]

19. Singh, P.; Magalhães, S.; Alves, L.; Antunes, F.; Miguel, M.; Lindman, B.; Medronho, B. Cellulose-based edible films for probiotic entrapment. Food Hydrocoll. 2019, 88, 68-74. [CrossRef]

20. Moslehi, Z.; Nafchi, A.M.; Moslehi, M.; Jafarzadeh, S. Aflatoxin, microbial contamination, sensory attributes, and morphological analysis of pistachio nut coated with methylcellulose. Food Sci. Nutr. 2021, 9, 2576-2584. [CrossRef] [PubMed]

21. Colín-Cruz, M.A.; Pimentel-González, D.J.; Carrillo-Navas, H.; Alvarez-Ramírez, J.; Guadarrama-Lezama, A.Y. Co-encapsulation of bioactive compounds from blackberry juice and probiotic bacteria in biopolymeric matrices. LWT Food Sci. Technol. 2019, 110, 94-101. [CrossRef]

22. Li, S.; Ma, Y.; Ji, T.; Sameen, D.E.; Ahmed, S.; Qin, W.; Dai, J.; Li, S.; Liu, Y. Cassava starch/carboxymethylcellulose edible films embedded with lactic acid bacteria to extend the shelf life of banana. Carbohydr. Polym. 2020, 248, 116805. [CrossRef]

23. Jahdkaran, E.; Hosseini, S.E.; Nafchi, A.M.; Nouri, L. The effects of methylcellulose coating containing carvacrol or menthol on the physicochemical, mechanical, and antimicrobial activity of polyethylene films. Food Sci. Nutr. 2021, 9, 2768-2778. [CrossRef]

24. Zabihollahi, N.; Alizadeh, A.; Almasi, H.; Hanifian, S.; Hamishekar, H. Development and characterization of carboxymethyl cellulose based probiotic nanocomposite film containing cellulose nanofiber and inulin for chicken fillet shelf life extension. Int. J. Biol. Macromol. 2020, 160, 409-417. [CrossRef]

25. Albadran, H.A.; Monteagudo-Mera, A.; Khutoryanskiy, V.V.; Charalampopoulos, D. Development of chitosan-coated agar-gelatin particles for probiotic delivery and targeted release in the gastrointestinal tract. Appl. Microbiol. Biotechnol. 2020, 5749-5757. [CrossRef] [PubMed]

26. Pruksarojanakul, P.; Prakitchaiwattana, C.; Settachaimongkon, S.; Borompichaichartkul, C. Synbiotic edible film from konjac glucomannan composed of Lactobacillus casei- $01^{\circledR}$ and Orafti ${ }^{\circledR}$ GR, and its application as coating on bread buns. J. Sci. Food Agric. 2020, 100, 2610-2617. [CrossRef] [PubMed]

27. Abedinia, A.; Nafchi, A.M.; Sharifi, M.; Ghalambor, P.; Oladzadabbasabadi, N.; Ariffin, F.; Huda, N. Poultry gelatin: Characteristics, developments, challenges, and future outlooks as a sustainable alternative for mammalian gelatin. Trends Food Sci. Technol. 2020, 104, 14-26. [CrossRef]

28. Rama, G.R.; Dullius, D.; Agnol, W.D.; Esquerdo, V.M.; Lehn, D.N.; de Souza, C.F.V. Ricotta whey supplemented with gelatin and collagen for the encapsulation of probiotic lactic acid bacteria. Food Sci. Technol. 2020. [CrossRef]

29. Abedinia, A.; Ariffin, F.; Huda, N.; Nafchi, A.M. Extraction and characterization of gelatin from the feet of Pekin duck (Anas platyrhynchos domestica) as affected by acid, alkaline, and enzyme pretreatment. Int. J. Biol. Macromol. 2017, 98, 586-594. [CrossRef]

30. Nazmi, N.N.; Isa, M.I.N.; Sarbon, N.M. Preparation and characterization of chicken skin gelatin/CMC composite film as compared to bovine gelatin film. Food Biosci. 2017, 19, 149-155. [CrossRef]

31. Qi, X.-M.; Liu, S.-Y.; Chu, F.-B.; Pang, S.; Liang, Y.-R.; Guan, Y.; Peng, F.; Sun, R.-C. Preparation and characterization of blended films from quaternized hemicelluloses and carboxymethyl cellulose. Materials 2016, 9, 4. [CrossRef] [PubMed]

32. Abedinia, A.; Ariffin, F.; Huda, N.; Nafchi, A.M. Preparation and characterization of a novel biocomposite based on duck feet gelatin as alternative to bovine gelatin. Int. J. Biol. Macromol. 2018, 109, 855-862. [CrossRef]

33. Benbettaïeb, N.; Kurek, M.; Bornaz, S.; Debeaufort, F. Barrier, structural and mechanical properties of bovine gelatin-chitosan blend films related to biopolymer interactions. J. Sci. Food Agric. 2014, 94, 2409-2419. [CrossRef] [PubMed]

34. Santana, J.C.C.; Gardim, R.B.; Almeida, P.F.; Borini, G.B.; Quispe, A.P.B.; Llanos, S.A.V.; Heredia, J.A.; Zamuner, S.; Gamarra, F.M.C.; Farias, T.M.B.; et al. Valorization of Chicken Feet By-Product of the Poultry Industry: High Qualities of Gelatin and Biofilm from Extraction of Collagen. Polymers 2020, 12, 529. [CrossRef] [PubMed]

35. Tan, C.-C.; Karim, A.A.; Uthumporn, U.; Ghazali, F.C. Effect of Thermal Treatment on the Physicochemical Properties of Emulsion Stabilized by Gelatin from Black Tilapia (Oreochromis mossambicus) Skin. Food Biophys. 2020, 15, 423-432. [CrossRef]

36. Sidira, M.; Kandylis, P.; Kanellaki, M.; Kourkoutas, Y. Effect of immobilized Lactobacillus casei on the evolution of flavor compounds in probiotic dry-fermented sausages during ripening. Meat Sci. 2015, 100, 41-51. [CrossRef] [PubMed]

37. Mei, L.X.; Nafchi, A.M.; Ghasemipour, F.; Easa, A.M.; Jafarzadeh, S.; Al-Hassan, A.A. Characterization of pH sensitive sago starch films enriched with anthocyanin-rich torch ginger extract. Int. J. Biol. Macromol. 2020, 164, 4603-4612. [CrossRef]

38. Soukoulis, C.; Yonekura, L.; Gan, H.-H.; Behboudi-Jobbehdar, S.; Parmenter, C.; Fisk, I. Probiotic edible films as a new strategy for developing functional bakery products: The case of pan bread. Food Hydrocoll. 2014, 39, 231-242. [CrossRef] 
39. Akman, P.K.; Bozkurt, F.; Dogan, K.; Tornuk, F.; Tamturk, F. Fabrication and characterization of probiotic Lactobacillus plantarum loaded sodium alginate edible films. J. Food Meas. Charact. 2020, 15, 84-92. [CrossRef]

40. AOCS. Official Methods and Recommended Practices of the American Oil Chemists' Society. Method Cd 8b-90: Peroxide value. 2003.

41. Dong, Q.Y.; Chen, M.Y.; Xin, Y.; Qin, X.Y.; Cheng, Z.; Shi, L.E.; Tang, Z.X. Alginate-based and protein-based materials for probiotics encapsulation: A review. Int. J. Food Sci. Technol. 2013, 48, 1339-1351. [CrossRef]

42. Soukoulis, C.; Singh, P.; Macnaughtan, W.; Parmenter, C.; Fisk, I.D. Compositional and physicochemical factors governing the viability of Lactobacillus rhamnosus GG embedded in starch-protein based edible films. Food Hydrocoll. 2016, 52, 876-887. [CrossRef]

43. Burgain, J.; Gaiani, C.; Cailliez-Grimal, C.; Jeandel, C.; Scher, J. Encapsulation of Lactobacillus rhamnosus GG in microparticles: Influence of casein to whey protein ratio on bacterial survival during digestion. Innov. Food Sci. Emerg. Technol. 2013, 19, 233-242. [CrossRef]

44. Burgain, J.; Scher, J.; Lebeer, S.; Vanderleyden, J.; Cailliez-Grimal, C.; Corgneau, M.; Francius, G.; Gaiani, C. Significance of bacterial surface molecules interactions with milk proteins to enhance microencapsulation of Lactobacillus rhamnosus GG. Food Hydrocoll. 2014, 41, 60-70. [CrossRef]

45. Soukoulis, C.; Behboudi-Jobbehdar, S.; Yonekura, L.; Parmenter, C.; Fisk, I.D. Stability of Lactobacillus rhamnosus GG in prebiotic edible films. Food Chem. 2014, 159, 302-308. [CrossRef]

46. Wu, H.; Lei, Y.; Zhu, R.; Zhao, M.; Lu, J.; Xiao, D.; Jiao, C.; Zhang, Z.; Shen, G.; Li, S. Preparation and characterization of bioactive edible packaging films based on pomelo peel flours incorporating tea polyphenol. Food Hydrocoll. 2019, 90, 41-49. [CrossRef]

47. Shakila, R.J.; Jeevithan, E.; Varatharajakumar, A.; Jeyasekaran, G.; Sukumar, D. Comparison of the properties of multi-composite fish gelatin films with that of mammalian gelatin films. Food Chem. 2012, 135, 2260-2267. [CrossRef] [PubMed]

48. Calame, W.; Weseler, A.R.; Viebke, C.; Flynn, C.; Siemensma, A.D. Gum arabic establishes prebiotic functionality in healthy human volunteers in a dose-dependent manner. Br. J. Nutr. 2008, 100, 1269-1275. [CrossRef]

49. Fu, N.; Chen, X.D. Towards a maximal cell survival in convective thermal drying processes. Food Res. Int. 2011, 44, 1127-1149. [CrossRef]

50. Braber, N.V.; Vergara, L.D.; Rossi, Y.; Aminahuel, C.; Mauri, A.; Cavaglieri, L.; Montenegro, M. Effect of microencapsulation in whey protein and water-soluble chitosan derivative on the viability of the probiotic Kluyveromyces marxianus VM004 during storage and in simulated gastrointestinal conditions. LWT 2020, 118, 108844. [CrossRef]

51. Ying, D.; Sun, J.; Sanguansri, L.; Weerakkody, R.; Augustin, M.A. Enhanced survival of spray-dried microencapsulated Lactobacillus rhamnosus GG in the presence of glucose. J. Food Eng. 2012, 109, 597-602. [CrossRef]

52. Kanmani, P.; Lim, S.T. Development and characterization of novel probiotic-residing pullulan/starch edible films. Food Chem. 2013, 141, 1041-1049. [CrossRef] [PubMed]

53. Zoghi, A.; Khosravi-Darani, K.; Mohammadi, R. Application of edible films containing probiotics in food products. J. Consum. Prot. Food Saf. 2020, 15, 307-320. [CrossRef]

54. Galus, S.; Lenart, A.; Voilley, A.; Debeaufort, F. Effect of oxidized potato starch on the physicochemical properties of soy protein isolate-based edible films. Food Technol. Biotechnol. 2013, 51, 403-409.

55. Fakhouri, F.M.; Costa, D.; Yamashita, F.; Martelli, S.M.; Jesus, R.C.; Alganer, K.; Collares-Queiroz, F.P.; Innocentini-Mei, L.H. Comparative study of processing methods for starch/gelatin films. Carbohydr. Polym. 2013, 95, 681-689. [CrossRef] [PubMed]

56. Tripathi, M.K.; Giri, S.K. Probiotic functional foods: Survival of probiotics during processing and storage. J. Funct. Foods 2014, 9 , 225-241. [CrossRef]

57. Lee, K.Y.; Shim, J.; Lee, H.G. Mechanical properties of gellan and gelatin composite films. Carbohydr. Polym. 2004, 56, 251-254. [CrossRef]

58. Meybodi, N.M.; Mortazavian, A.M.; Arab, M.; Nematollahi, A. Probiotic viability in yoghurt: A review of influential factors. Int. Dairy J. 2020, 109, 104793. [CrossRef] 